\title{
The Effect Of Employee Ethical Ideology On Organizational Budget Slack: An Empirical Examination And Practical Discussion
}

Mary Ellen Harvey, Ramapo College of New Jersey, USA

\begin{abstract}
Budget slack costs institutions money because there is a misallocation of assets. Therefore, organizations have a vested interest in hiring managers who do not have a propensity toward creating slack. Budget slack results when managers intentionally include more organizational resources in the budget than they anticipate needing (or when they understate revenue-producing activities). Extensive time and effort is invested into a company's budgeting process. The budget is often the primary point of financial control over the distribution of organizational resources (i.e., time, money, and materials). Prior research in business ethics has attempted to explain and predict when a manager will engage in this behavior, examining antecedents such as budget participation, cultural differences, and reward systems. The current paper expands on previous studies and examines the influence of individual ethical factors. Specifically, the influence of an individual's ethical ideology is examined in relationship to their propensity to create budget slack.
\end{abstract}

Keywords: Budget Slack; Ethical Ideology; Business Ethics

\section{INTRODUCTION}

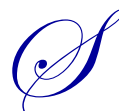

imply stated, research studies on budget slack are important to organizations because slack is costly. Budget slack occurs when an employee intentionally misstates the necessary budget resources, anticipated revenues, or expected production. It is a significant problem for organizations because creation of this slack is ordinarily in direct conflict with the economic interest of the organization. It results in inefficient distribution and utilization of enterprise resources. Specifically, financing costs, working capital management, compensation payments, and capital budgeting decisions can all be affected adversely by inaccurate budget planning. In addition, the effects of budget slack tend to perpetuate as historical budgets often are used as a basis for future planning. Research has identified certain potential antecedents, such as level of budget participation/shared information (Church, Hannan, \& Kuang, 2012; Fisher, Maines, Peffer, \& Sprinkle, 2002; Rankin, Schwartz, \& Young, 2008), cultural differences (Douglas \& Weir, 2005; Wu, 2005) and reward systems (Chen, 2012; Leavins, Omer, \& Vilutis, 1995). The results of this research, however, offer no conclusive answers.

For a substantial period, the ethical literature has been calling for more consideration of the role of ethical ideology in business settings (Barnett, Bass, Brown, \& Herbert, 1998; Giacalone, Fricker, \& Beard, 1995). While some studies responded and examined the relationship between budget slack and variety of ethical attributes (Douglas \& Wier 2000; Douglas \& Wier, 2005; Shafer \& Wang, 2011; Stevens, 2002), this line of research remains generally unexplored. The current research seeks to fill this gap by empirically examining the influence of an individual's ethical ideology on the propensity to create budgetary slack. 


\section{CONCEPTUAL FRAMEWORK}

\section{Ethical Ideology}

Schlenker and Forsyth (1977) believed individuals integrate multiple moral philosophies in decisionmaking. Moral philosophy refers to the rules and principles considered by an individual during decision-making in order to distinguish between right and wrong. Generally, the various schools of philosophy can be classified as teleological or deontological (Ferrell, Fraedrich, \& Ferrell, 2000; Fritzche \& Becker, 1984; Hunt \& Vitell, 1986; Schlenker \& Forsyth, 1977). Teleological evaluations examine the consequences of an action and deontology evaluations focus on proper behavior. In addition to deontology and teleology, Schlenker and Forsyth (1977) describe a third category - labeled skepticism. Skepticism emerged as a result of dissension over the two primary moral philosophies. Schlenker and Forsyth believed the differences between the three categories of philosophy could be measured and would represent an individual's level of idealism and relativism. They posited that different ethical ideologies, measured via these two constructs, might help explain why individuals with similar backgrounds and characteristics interpret ethical situations differently (Forsyth, 1980).

The first construct - idealism - captures the degree to which an individual believes a potentially harmful act is always avoidable. Idealists believe this is always possible, while non-idealists (i.e., pragmatists) accept that certain harm may be necessary to bring about the best overall result. The second construct represents relativism. Relativists believe an ethical judgment regarding a particular situation cannot be made based on a predetermined set of moral dictates. Situational and individual factors can and should be considered. On the other hand, strict nonrelativists believe adherence to universal moral rules is the criteria by which an action should be deemed moral or not (Forsyth, 1980).

Forsyth (1980) used the two dimensions of idealism and relativism to develop a 2 X 2 taxonomy of ethical ideology. Forsyth suggested, that depending where along the continuum of each scale an individual fell, he or she could be classified into one of four ethical ideologies and that individuals within each category would vary in their moral judgments. Table 1 summarizes Forsyth's taxonomy.

Table 1: Forsyth's Taxonomy Of Ethical Ideology

\begin{tabular}{|c|c|c|}
\hline & High Relativism & Low Relativism \\
\hline High Idealism & $\begin{array}{l}\text { Situationists } \\
\text { - } \quad \text { Reject moral codes } \\
\text { - } \quad \text { Judge action based on best situational } \\
\text { outcome } \\
\text { - } \quad \begin{array}{l}\text { Deception can be used if it yields the best } \\
\text { situational outcome } \\
\text { - } \quad \text { Idealistic skeptic }\end{array} \\
\end{array}$ & $\begin{array}{l}\text { Absolutists } \\
\text { - } \quad \text { Accept moral codes } \\
\text { - } \quad \text { Ethical decisions must not harm others } \\
\text { - } \quad \text { Deception should be avoided since it violates } \\
\text { - } \quad \text { fundamental moral principles. } \\
\text { Deontologist }\end{array}$ \\
\hline Low Idealism & 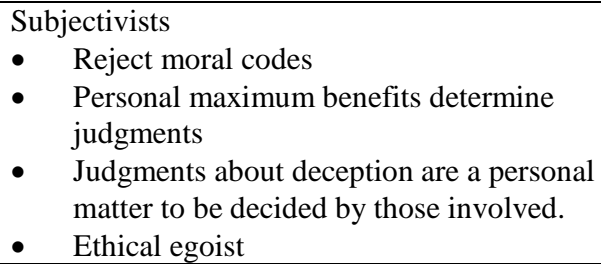 & $\begin{array}{l}\text { Exceptionists } \\
\text { - } \quad \text { Accept moral codes, but open to exceptions } \\
\text { - } \quad \text { Optimal outcome not possible for all } \\
\text { - If the deception cannot be avoided, then the } \\
\text { deception is allowable if safeguards are used. } \\
\text { - Teleologist; utilitarian }\end{array}$ \\
\hline
\end{tabular}

From Forsyth and Pope (1984, p. 1366) and Bass, Barnett, and Brown (1998, p. 3).

In 1980, Forsyth advanced a final version of the Ethics Position Questionnaire (EPQ), consisting of two scales measuring an individual's level of idealism and relativism. A series of empirical studies firmly established a relationship between ethical ideology and ethical decision-making (e.g., Forsyth, 1981; Forsyth \& Pope, 1984). A decade later, Forsyth (1992) suggested that ethical ideology might play an important role in influencing an individual's decision to participate in certain business practices. Subsequent studies concluded that an individual's ethical ideology did, in fact, influence judgment pertaining to ethically questionable actions and decisions in business settings (e.g., Barnett, Bass, \& Brown, 1994; Beekun, Hamdy, Westerman, \& HassabElnaby, 2008; Douglas \& Wier, 2005; Valentine, Young, Bailey, \& Barhoum, 2001). 


\section{Budget Slack}

The concept of budgetary slack is rooted in the organizational theories of Cyert and March (1963) and agency theory (Merchant, 1985; Riahi-Belkaoui, 1994). For 40 years, substantial time and attention has been devoted to the issue of budget slack. Conceptual and empirical research clearly indicates that budgetary slack permeates business organizations and has the potential to result in significant adverse economic consequences (Davila \& Wouters, 2005; Merchant, 1985; Schiff \& Lewin, 1968; Schwartz, Spires, Wallin, \& Young, 2012).

In 1963, Cyert and March developed a theoretical model, which included both cognitive and structural factors, to explain the creation of organizational slack. Cyert and March defined organizational slack as the "disparity between the resources available to the organization and the payments required to maintain the coalition." (p. 36). Merchant (1985) later pointed out that many semantic differences exist among theorists when discussing the concept of slack, ranging from traditional agency terms such as "excess consumption of prerequisites" to behavioral study terms such as "managerial biasing" and "deceptive behaviors". In 1994, Riahi-Belkaoui offered a definitional bridge between organizational slack and budget slack suggesting that managers are motivated to operate in a slack environment and the budgeting process provides ample opportunity to do so.

Agency theory provides a basis for understanding why an individual may be motivated to act in a manner that creates slack. The underlying assumptions of agency theory include the belief that individuals will act in their own best self-interest and the nature of the enterprise consists of various contractual relationships (e.g., between management and owners) (Wolk, Francis, \& Tearney, 1992). While the motivation to protect oneself is understandable when working in competitive, performance-linked reward environments, it is ordinarily in direct conflict with the economic interest and budget objectives of the organization (Merchant, 1985).

Onsi (1973) provides a formal, economically-based model explaining why slack has the potential to be detrimental to an organization. He states, "The existence of budgetary slack causes corporate profits to be less than optimum since the estimated cost function is not minimum in classic economic theory." (p. 35). Interestingly, he continues to suggest that one should look to how the excess resources are being used before concluding whether budget slack is desirable or not. Merchant (1985) also submits that slack, if used strategically, may not be an absolute negative. Despite the potential for slack to have a positive influence (Elmassri \& Harris, 2011), most researchers and the literature generally agree that it is costly to organizations and warrants empirical investigation in order to identify (and control) the antecedents.

In 1998, Dunk and Nouri synthesized the existing research on budget slack and distinguished three categories of variables that potentially impact the creation of budgetary slack - organizational, individual, and environmental. In 2000, Douglas and Wier used structural equation analysis to establish a relationship between ethical ideology and slack. Despite years of empirical research exploring the nature of budget slack, there remains an information gap regarding the contributing factors. The paper presented here responds to this and seeks to contribute to the body of knowledge surrounding the influence of ethical ideology on budget slack.

\section{RESEARCH DESIGN}

\section{Hypothesis Development}

Individual factors, such as ethical ideology, have been shown to influence employees in the workplace. Based on the literature review, the following hypotheses were developed to test the influence of individual ethical ideology and the propensity to create budget slack:

$\mathbf{H}_{1:}$ An individual's level of relativism will be positively related to the propensity to create budgetary slack.

$\mathbf{H}_{2}$ : An individual's level of idealism will be negatively related to the propensity to create budgetary slack. analysis.

The primary statistical technique used to conclude on the two proposed hypotheses was correlation 


\section{Sample Selection}

Budget slack is cross-sectional. It affects organizations operating in all types of industries and environments. The sample selection for this study, therefore, sought to obtain data that would reflect this. The participants consisted of business program students who were employed full-time within the past six months from a wide variety of organizations. Demographic data were collected to identify characteristics of the sample and help to ensure that the questionnaire data included were consistent with the sample criteria. In order to maximize the includable instruments, the sample was drawn from master's level students, evening classes, and students taking upper level classes.

The survey was administered as an in-class voluntary assignment to nearly 300 participants. Respondents who had not been full-time employed within the past six months or who did not fully complete the questionnaire were eliminated from the analysis. The effective response rate was 62 percent (179 usable questionnaires) with representation from the service sector (43 percent), manufacturing ( 21 percent) and retail (11 percent).

\section{Measurement Of Variables}

Forsyth's 1980 Ethics Position Questionnaire (EPQ) was used to measure the independent variable - ethical ideology. This scale consists of 20 items, which factor and correlational analysis have shown to measure an individual's degree of relativism and idealism. The EPQ was also chosen because it's considered "philosophically unbiased"; it does not rank the different ethical ideologies, but instead simply measures the construct (Tansey, Brown, Hyman, \& Dawson, 1994). The current study's dependent variable - propensity to create budget slack - is measured using Onsi's 1973 measure of "slack attitude", which is based on the organizational theories of Cyert and March (1963). Both the EPQ and Onsi's scale have been widely used in research and have established records of reliability and validity. This is important in order to ensure that the questionnaire responses will measure what they purport to, and will do it consistently. Social desirability - a category of response bias - was also assessed. Paulhus (1991) defines it simply as "the tendency to give answers that make the respondent look good" (p. 17). The questionnaire used in this research asked respondents to self-report on attitudes and behaviors that are ethically sensitive; therefore, it warranted consideration. Response bias was measured using a short form of the MarloweCrowne social desirability scale, developed by Strahan and Gerbasi (1972). Correlation analysis was applied to test for statistical significance between social desirability and each of the three study variables (i.e., slack, idealism, relativism). Only idealism tested significantly with social desirability and, accordingly, the analysis for hypothesis two includes a correction for response bias impact. Finally, Cronbach's alpha was calculated for each of the variables in the current study to measure the internal consistency. Table 2 indicates the results which were consistent with prior studies and generally considered acceptable (Nunnally, 1978).

Table 2: Cronbach Alpha's

\begin{tabular}{|l|c|}
\hline Scale Name & Cronbach's Alpha \\
\hline Idealism & .87 \\
\hline Relativism & .79 \\
\hline Budget Slack & .69 \\
\hline
\end{tabular}

A pretest of the questionnaire was conducted to solicit feedback on the clarity of the instructions and the questions and evident problems. The pretest participants were from the same population as the larger test but were not members of the group who participated in the primary test, to eliminate the possibility of pretest sensitization (Huck \& Cormier, 1996).

\section{RESULTS}

As discussed above, this study focused on two research questions involving the relationship between ethical ideology and budget slack. The theory and literature support the hypothesis that individuals who are identified as relativists would be more likely to believe budget slack is justified. 
Pearson's correlation coefficients were used to evaluate the research questions. Table 3 summarizes the results. Statistical significance was evaluated for each hypothesis based on the reported p-value. The scores from each Likert-like scale were combined to produce an index to allow for comparative analysis of scales containing different characteristics (i.e., Likert ranges). Two-tailed Pearson first-order partial correlation coefficients were calculated for all the study variables in order to assess the strength of the relationships between them. There does not appear to be any evidence of multicollinearity.

\section{Will Ethical Ideology Really Make A Difference?}

$\mathbf{H}_{1:}$ An individual's level of relativism will be positively related to the propensity to create budgetary slack.

A one-tailed Pearson's bivariate correlation coefficient was used as the basis to evaluate the first hypothesis. The results indicated a positive correlation between propensity to create budgetary slack and an individual's level of relativism $(\mathrm{r}=.21)$. This effect was found to be statistically significant $(\mathrm{p}=.002)$; in summary, the level of relativism was found to have a positive direct relationship with an individual's propensity to create budget slack.

$\mathbf{H}_{2}$ : An individual's level of idealism will be negatively related to the propensity to create budgetary slack.

A one-tailed, Pearson's first-order partial correlation coefficient was used as the basis to assess hypothesis two. This procedure was appropriate because it allowed for social desirability to be entered as a control variable. The analysis indicated the coefficient was slightly positive (.01) but not statistically significant ( $\mathrm{p}=.442)$. Therefore, there is no evidence idealistic employees would be less likely to sanction budget slack.

Table 3: Correlation Coefficients

\begin{tabular}{|l|c|c|c|}
\hline & $\mathbf{1}$ & $\mathbf{2}$ & $\mathbf{3}$ \\
\hline 1.Idealism & 1.00 & & \\
\hline 2.Relativism & .07 & 1.00 & 1.00 \\
\hline 3.Slack & .01 & $.21 * *$ & \\
\hline
\end{tabular}

** Correlation is significant at the .01 level $(\mathrm{p}<.01)$.

\section{DISCUSSION AND CONCLUSIONS}

Although the results from Hypothesis 2 were inconclusive, Hypothesis 1 found statistical evidence that relativism and the propensity to create budget slack were positively related. This relationship is theoretically founded. Relativists are inclined to make decisions on a situational basis rather than by applying ecumenical moral rules. Budget slack, which tends to be beneficial to an individual and detrimental to the organization, is, in effect, a misstatement. The tenets of agency theory (i.e., individuals act in their own best self-interest), coupled with the evaluation structure of many organizations, help explain why individuals who are more relativist would be more likely to rationalize the creation of budget slack. Extensive time and effort is invested into a company's budgeting process. The budget is often the primary point of financial control over the distribution of organizational resources (i.e., time, money, and materials). Budget slack costs institutions money because there is a misallocation of assets. Therefore, they have a vested interest in making staffing decisions that do not leave the company more vulnerable to the generation of, and ramifications related to, budget slack. The results of this study provide incentive for organizations to consider the potential increased exposure of placing an employee who is a relativist in a position with budgetary discretion.

\section{AUTHOR INFORMATION}

Dr. Mary Ellen Harvey is an associate professor of Accounting in the Anisfield School of Business, Ramapo College of New Jersey. Her research interests include application of ethics in business, management accounting and auditing. Email: mharvey@ ramapo.edu. 


\section{REFERENCES}

1. Barnett, T., Bass, K., \& Brown, G. (1994). Ethical ideology and ethical judgement regarding ethical issues in business. Journal of Business Ethics, 13(6), 469-480.

2. Barnett, T., Bass, K., Brown, G., \& Hebert, F. (1998). Ethical ideology and the ethical judgements of marketing professionals. Journal of Business Ethics, 17(7), 715-723.

3. Bass, K., Barnett, T., \& Brown, G. (1998). The moral philosophy of sales managers and its influence on ethical decision making. The Journal of Personal Selling \& Sales Management, 18(2), 1-17.

4. Beekun, R. I., Hamdy, R., Westerman, J. W., \& HassabElnaby, H. R. (2008). An exploration of ethical decision-making processes in the United States and Egypt. Journal of Business Ethics, 17(82), 587-605.

5. Chen, M. (2012). The effect of leader reward and punishment behaviors on subordinates' budget reports. The Engineering Economics, 57, 41-54.

6. Church, B. K., Hannan, R. L., \& Kuang, X. (2012). Shared interest and honesty in budget reporting. Accounting, Organizations and Society, 37, 155-167.

7. Cyert, R., \& March, J. (1963). A behavioral theory of the firm. Englewood Cliffs, NJ: Prentice-Hall Publishing Company.

8. Davila, T., \& Wouters, M. (2005). Managing budget emphasis through the explicit design of conditional budgetary slack. Accounting, Organizations and Society, 30(7-8), 587-608.

9. Douglas, C. D., \& Wier, B. (2000). Integrating ethical dimensions into a model of budgetary slack creation. Journal of Business Ethics, 28(3), 267-277.

10. Douglas, C. D., \& Wier, B. (2005). Cultural and ethical effects in budgeting systems: A comparison of U.S. Chinese managers. Journal of Business Ethics, 60(2), 159-174.

11. Dunk, A., \& Nouri, H. (1998). Antecedents of budget slack: A literature review and synthesis. Journal of Accounting Literature, 17, 72-96.

12. Elmassri, M., \& Harris, E. (2011). Rethinking budgetary slack as risk management. Journal of Applied Accounting Research, 12(3), 278-293.

13. Ferrell, O. C., Fraedrich, J., \& Ferrell, L. (2000). Business ethics: Ethical decision making and cases. $\left(4^{\text {th }}\right.$ ed.). New York, NY: Houghton Mifflin Company.

14. Fisher, J. G., Maines, L. A., Peffer, S. A., \& Sprinkle, G. B. (2002). Using budgets for performance evaluations: Effects of resource allocation and horizontal information asymmetry on budget proposals, budget slack, and performance. The Accounting Review, 77(4), 847-865.

15. Forsyth, D. R. (1980). A taxonomy of ethical ideologies. Journal of Personality and Social Psychology, 39(1), 175-184.

16. Forsyth, D. R. (1981). Moral judgment: The influence of ethical ideology. Personality and Social Psychology Bulletin, 7(2), 218-223.

17. Forsyth, D. R. (1992). Judging the morality of business practices: The influence of personal moral philosophies. Journal of Business Ethics, 11(5), 461-470.

18. Forsyth, D. R., \& Pope, W. R. (1984). Ethical ideology and judgements of social psychological research: Multidimensional analysis. Journal of Personality and Social Psychology, 6(6), 1365-1375.

19. Fritzche, D. J., \& Becker, H. (1984). Linking management behavior to ethical philosophy. Academy of Management Journal, 27(1), 166-175.

20. Giacalone, R. A., Fricker, S., \& Beard, J. W. (1995). The impact of ethical ideology on modifiers of ethical decisions and suggested punishment for ethical infractions. Journal of Business Ethics, 14(7), 497-510.

21. Huck, S. W., \& Cormier, W. H. (1996). Reading statistics and research. (2 ${ }^{\text {nd }}$ ed.). New York, NY: HarperCollins Publishers.

22. Hunt, S. D., \& Vitell, S. (Spring, 1986). A general theory of marketing ethics. Journal of Macromarketing, 5-15.

23. Leavins, J., Omer, K., \& Vilutis, A. (1995). A comparative study of alternative indicators of budgetary slack. Managerial Finance, 21(3), 52-67.

24. Merchant, K. A. (1985). Budgeting and the propensity to create budgetary slack. Accounting, Organizations and Society, 10(2), 201-210.

25. Nunnally, J. C. (1978). Psychometric theory. ( $2^{\text {nd }}$ ed.). New York, NY: McGraw-Hill Book Company.

26. Onsi, M. (1973). Factor analysis of behavioral variables affecting budgetary slack. The Accounting Review, 48(3), 535-548. 
27. Paulhus, D. (1991). Measurement and control of response bias. In Measures of social psychological attitudes, edited by Robinson, J. P., Shaver, P. R., \& Wrightsman, L., 17-41. New York, NY: Academic Press.

28. Rankin, F. W., Schwartz, S. T., \& Young, R. A. (2008). The effect of honesty and superior authority on budget proposals. The Accounting Review, 83(4), 1083-1099.

29. Riahi-Belkaoui, A. (1994). Organizational and budgetary slack. Westport, CT: Quorum Books.

30. Schiff, M., \& Lewin, A. Y. (1968). Where traditional budgeting fails. Financial Executive, 36(5), 51-62.

31. Schlenker, B. R., \& Forsyth, D. R. (1977). On the ethics of psychological research. Journal of Experimental Social Psychology, 13, 369-396.

32. Schwartz, S. T., Spires, E. E., Wallin, D. E., \& Young, R. A. (2012). Aggregation in budgeting: An experiment. Journal of Management Accounting Research, 24, 177-199.

33. Shafer, W. E., \& Wang, Z. (2011). Effects of ethical context and Machiavellianism on attitudes towards earnings management in China. Managerial Auditing Journal, 26(5), 372-392.

34. Stevens, D. E. (2002). The effects of reputation and ethics on budgetary slack. Journal of Management Accounting Research, 14, 153-169.

35. Strahan, R., \& Gerbasi, K. C. (1972). Short, homogeneous versions of the Marlowe-Crowne social desirability scale. Journal of Clinical Psychology, 28, 191-193.

36. Tansey, R., Brown, G., Hyman, M. R., \& Dawson, L. E. (1994). Personal moral philosophies and the moral judgements of salespeople. Journal of Personal Selling \& Sales Management, 14(1), 59-75.

37. Valentine, S., Young, K., Bailey, L., \& Barhoum, N. (2001). Expressing organizational dissent: The role of ethical ideology and corporate ethical values. Journal of Business Strategies, 1(1), 71-89.

38. Wolk, H., Francis, J., \& Tearney, M. (1992). Accounting theory. ( $3^{\text {rd }}$ ed.). Cincinnati, OH: South-Western Publishing Company.

39. Wu, E. C. (2005). Convergence of attitudes in different cultures towards the budgeting process. Journal of Business and Management, 11(29), 29-47. 


\section{NOTES}

